Клімова А. В. ${ }^{[1 ; 0 R C I D ~ I D ~: ~ 0000-0003-0051-3925], ~}$ здобувач вищої освіти третього (освітньо-наукового) рівня, завідувач відділу ліцензування та акредитації

${ }^{1}$ Національний університет водного господарства та природокористування, м. Рівне

\title{
ВДОСКОНАЛЕННЯ ОРГАНІЗАЦІЙНОЇ СТРУКТУРИ ЗАКЛАДІВ ВИЩОЇ ОСВІТИ 3 МЕТОЮ ПІДВИЩЕННЯ ЕФЕКТИВНОСТІ ЛІЦЕНЗІЙНОӤ ТА ГОСПОДАРСЬКОї ДІЯЛЬНОСТІ
}

Активне входження закладів вищої освіти України в Європейський освітній простір, демографічний спад, що посилює конкуренцію на ринку освітніх послуг, реформування системи вищої освіти, системи ліцензування освітньої діяльності, запровадження автономії закладів вищої освіти, в т.ч. академічної і фінансової, ставить перед закладами освіти необхідність розробляти нові стратегії розвитку, що вимагає застосування нових інструментаріїв і технологій маркетингу. Маркетинг освітніх послуг має на меті формування закладами вищої освіти стратегії і тактики поведінки на ринку освітніх послуг. Зважаючи, на те, що заклади освіти виходять на ринок зі специфічним товаром, таким як освітня послуга, формування якого має базуватися на потребах внутрішніх $\mathbf{i}$ зовнішніх стейкхолдерів, необхідно звернути увагу на повноту інформаційно-аналітичного забезпечення, що передує прийняттю управлінських рішень. У даній статті проведено аналіз достатності інформаційного та аналітичного забезпечення прийняття рішень закладами вищої освіти щодо входження в нові сектори ринку освітніх послуг, прийняття рішень про запровадження нових освітніх програм та удосконалення існуючих. Запропоновано шляхи удосконалення організаційної структури закладів вищої освіти 3 метою розробки нових стратегій розвитку для стимулювання економічних результатів господарської діяльності та підвищення ефективності ліцензійної діяльності. Описаний соціально-економічний вплив запропонованих заходів з метою прийняття обґрунтованих управлінських рішень.

Ключові слова: ліцензування; економіка; заклади вищої освіти; ринок праці; ринок освітніх послуг; стратегія управління; інформаційноаналітична діяльність.

Постановка проблеми. В умовах розвитку ринку освітніх послуг, тенденцій глобалізації та інтернаціоналізації закладів вищої освіти велике соціально-економічне значення набуває розвиток вищої освіти та забезпечення високих показників якості освіти закладами вищої освіти. Прийняття управлінських рішень щодо розвитку 
освітньої діяльності закладу освіти потребує постійного вивчення як внутрішнього, так і зовнішнього середовища, врахування багатьох факторів, в тому числі соціальних та економічних. Ефективність економічної діяльності закладу освіти залежить від організації надходження інформації, від обробки та аналізу інформації, а також від об'єктивності використання отриманої інформаціі. Останні зміни в нормативно-правовому полі освіти України потребують від закладів вищої освіти перебудови системи прийняття управлінських рішень, розробки та активного застосування маркетингових стратегій розвитку. Тому пошук найбільш дієвих інструментів при прийнятті рішень щодо ліцензійної діяльності та стимулювання підвищення ефективності економічної діяльності закладів вищої освіти сформувало мету, предмет та актуальність даного дослідження.

Аналіз останніх досліджень і публікацій. Питання управління діяльністю закладами освіти та маркетингу освітніх послуг в своїх роботах розглядають С. Ніколаєнко, І. Шарабура, Ф. Котлер, Т. Оболенська, І. Решетнікова, М. Сабурова, О. Євсейцева.

Проте саме питанням вдосконалення організаційної структури закладу вищої освіти з метою дослідження ринку праці та ринку освітніх послуг, проведення ефективної інформаційно-аналітичної роботи з метою подальшого прийняття об'єктивних управлінських рішень щодо позиціювання та просування закладів освіти на ринку не приділено достатньої уваги. Все це зумовило предмет даного дослідження.

Постановка завдання. Дослідити шляхи вдосконалення організаційної структури 3ВО, оцінити соціально-економічний вплив запропонованих заходів 3 метою підвищення ефективності ліцензійної діяльності та стимулювання економічних результатів діяльності ЗВО на ринку освітніх послуг.

Виклад основного матеріалу. Входження закладів вищої освіти України в конкурентну боротьбу на ринку освітніх послуг в умовах складної демографічної ситуації, боротьби за абітурієнтів між закладами закладів державної форми власності, які підвищують свою конкурентоспроможність наданням якісних освітніх послуг, та приватної форми власності, які часто формують свою конкурентоспроможність за рахунок зменшення ціни за освітні послуги. Погоджуючись 3 думкою Т. Оболенської, що «освітня послуга $€$ специфічним товаром, який задовольняє прагнення людини в придбанні певних знань, умінь та навичок для їх подальшого використання в професійній діяльності» [1], можна вважати, що роль закладів вищої освіти заключається не лише у 
підготовці високоосвічених фахівців, а й вивчені потреб сьогодення на знання та формуванні освітньої послуги на основі потреб внутрішніх і зовнішніх стейкхолдерів. Фактично освітні програми $\epsilon$ тим товаром, що дозволяє формувати стратегію маркетингу закладу вищої освіти. Реформування вищої освіти вимагає переосмислення ролі інструментів маркетингу освітніх послуг.

Будучи суб'єктами ринку освітніх послуг заклади вищої освіти в недостатній мірі використовують принципи ринкоорієнтованої діяльності, що призводить до виникнення ряду проблем у сфері управління, до яких можна віднести:

- обмежене використання маркетингових досліджень, у тому числі досліджень конкурентів і споживачів;

- зосередженість на вирішенні переважно внутрішніх завдань, слабка взаємодія із споживачами освітніх послуг для кращого розуміння їхніх потреб і ступеня задоволеності;

- відсутність системи прийняття управлінських рішень на випередження, уповільнена реакція на зміни в зовнішньому середовищі;

- орієнтація на досягнення цілей і завдань короткострокового періоду

- низький рівень адаптації структур управління закладами освіти до ринкових умов та домінування задач оперативного управління

- недостатній рівень застосування окремих важливих управлінських функцій, таких як довгострокове планування, контроль [2].

Керівництво закладом вищої освіти здійснюючи управлінську діяльність повинно використовувати принцип інформаційної достатності, від якого залежить ефективність внутрішнього управління закладом, та принцип прогностичності внутрішнього управління, оскільки заклад має постійні зв'язки із зовнішнім середовищем, від яких залежить його діяльність і враховує багато факторів, зокрема економічні і соціальні. Освітній заклад має постійно вивчати вплив різних факторів і перебудовувати свій освітній процес в залежності від впливу зовнішнього середовища. Принцип об'єктивності і повноти інформації має використовувати керівництво закладу вищої освіти не лише для отримання інформації про внутрішній стан справ, серед яких задоволеність стейкхолдерів, освітня, навчально-методична, наукова та виховна робота, викладання, успішність здобувачів вищої освіти, а й інформацію, пов'язану із зовнішнім середовищем для побудови ефективної 
стратегії розвитку закладу, зокрема ринок праці, ринок освітніх послуг. Об'єктивність і повнота інформації потрібна на усіх етапах управління закладом вищої освіти, при прийнятті рішень, зокрема, починаючи від етапу аналізу, планування та організації освітньої діяльності, під час контролю та корегування. Ефективність діяльності закладу освіти залежить від організації надходжень інформації, обробки і аналізу інформації та подальшого використання отриманої інформації.

Важко не погодитися 3 думкою І. Решетнікової, що «незважаючи на актуальність застосування маркетингу на ринку освіти, в свідомості керівників закладів вищої освіти маркетинг в освіті зводиться головним чином до активного пошуку майбутніх абітурієнтів і агресивної рекламної кампанії» [3; 4]. Із входженням України в Європейській освітній простір та зміною системи акредитації освітніх програм відповідно до Стандартів і рекомендацій щодо забезпечення якості в Європейському просторі вищої освіти (ESG-2015), активної розбудови внутрішньої системи якості закладами вищої освіти почала приділятися велика увага маркетингу внутрішнього ринку.

На сьогоднішній день закладами вищої освіти практично не проводиться комплекс інформаційно-аналітичної роботи на стадії прийняття рішення про ліцензування спеціальності, а також відкриття освітньої програми, тому основні принципи маркетингу, такі як системність, комплексність, регулярність, об'єктивність, точність, економічність та оперативність, практично не впливають на стратегію діяльності та розвитку закладу вищої освіти, що призводить до неефективної діяльності в ринкових умовах, оскільки заклад вищої освіти змушений продавати той товар (освітню послугу), що виробляє, а результативність ліцензійної діяльності $€$ суперечливою і не завжди ефективною. 3 метою прийняття рішення про запровадження нових спеціальностей та розробки нових освітніх програм за вже існуючими спеціальностями заклад вищої освіти має проводити комплексні дослідження, що передбачають сегментацію ринку освітніх послуг та об'ємної інформаційно-аналітичної роботи у вивчені потреб цільових груп стейкхолдерів (як зовнішніх, так і внутрішніх); пропозицій та унікальності освітніх програм на ринку освітніх послуг; розподіл освітніх послуг на ринку; можливих конкурентів як в регіоні, так і в Україні; якість надання освітніх послуг; ціноутворення; проводити аналіз власних ресурсів для започаткування нових освітніх програм та витрат, необхідних для їх запровадження. 
Налагодження ретельної інформаційно-аналітичної роботи закладами вищої освіти вимагають і останні зміни в законодавстві про вищу освіту 2020 року в частині ліцензування освітньої діяльності, відповідно до яких заклади вищої освіти отримуватимуть ліцензії на здійснення освітньої діяльності у сфері вищої освіти окремо на кожен рівень вищої освіти, а не за спеціальністю на кожному рівні вищої освіти. Маючи ліцензію на освітню діяльність в межах певного рівня вищої освіти заклад зможе запроваджувати освітні програми за будь якою спеціальність з умовою дотримання Ліцензійних умов провадження освітньої діяльності. Окремо підлягатимуть ліцензуванню освітні програми щодо підготовки фахівців за регульованими професіями, перелік яких встановлюватиметься Міністерством освіти і науки України. Згідно з проєктом нормативно-правового документу, оприлюдненого Міністерством освіти і науки України до таких спеціальностей можуть бути віднесені 28 спеціальностей із 121 існуючої в Україні.

3 метою налагодження та поглиблення інформаційноаналітичної роботи закладам вищої освіти доцільно створювати інформаційно-аналітичний відділ як окремої складової комплексу маркетингу, який має стати ключовим, оскільки при побудові ефективного менеджменту головну роль грає первинна інформація про кон'юнктуру ринку, попит, а також зворотній зв'язок зі стейкхолдерами. Основним завданням такого відділу має стати детальне вивчення та постійне оновлення інформації про потреби ринку праці, потреби сучасних стейкхолдерів, відстеження головних трендів на ринку освітніх послуг та розробка відповідних пропозицій, які ляжуть в основу стратегії розвитку закладу вищої освіти.

При виборі структури відділу варто віддати перевагу матричній структурі 3 організацією роботи за проєктним принципом, що передбачає створення проєктних груп з фахівців зазначеного відділу та фахівців з числа науково-педагогічних працівників, які $\epsilon$ ініціаторами започаткування нової спеціальності або відкриття нової освітньої програми в межах вже існуючої спеціальності. Структура відділу представлена на рисунку.

Зазначена організаційна структура інформаційно-аналітичної діяльності передбачає в побудові роботи над проєктом закріплення двох напрямів керівництва: функціонального - зі сторони відділу та проєктного - зі сторони структурного підрозділу закладу вищої освіти (інституту, факультету, кафедри), а також наявність головного керівника проєкту, який збалансовує два напрями керівництва в системі та по завершенню аналітичної роботи представляє 
інформацію для подальшого вирішення питання щодо продовження проєкту. Головним керівником проєкту на стадії аналітичної роботи $\epsilon$ представник інформаційно-аналітичного відділу 3 подальшою передачею цих функцій керівникові освітньої програми. Інформаційно-аналітичний відділ супроводжує проєкт в межах своїх функціональних обов'язків до проходження первинної акредитації освітньої програми.

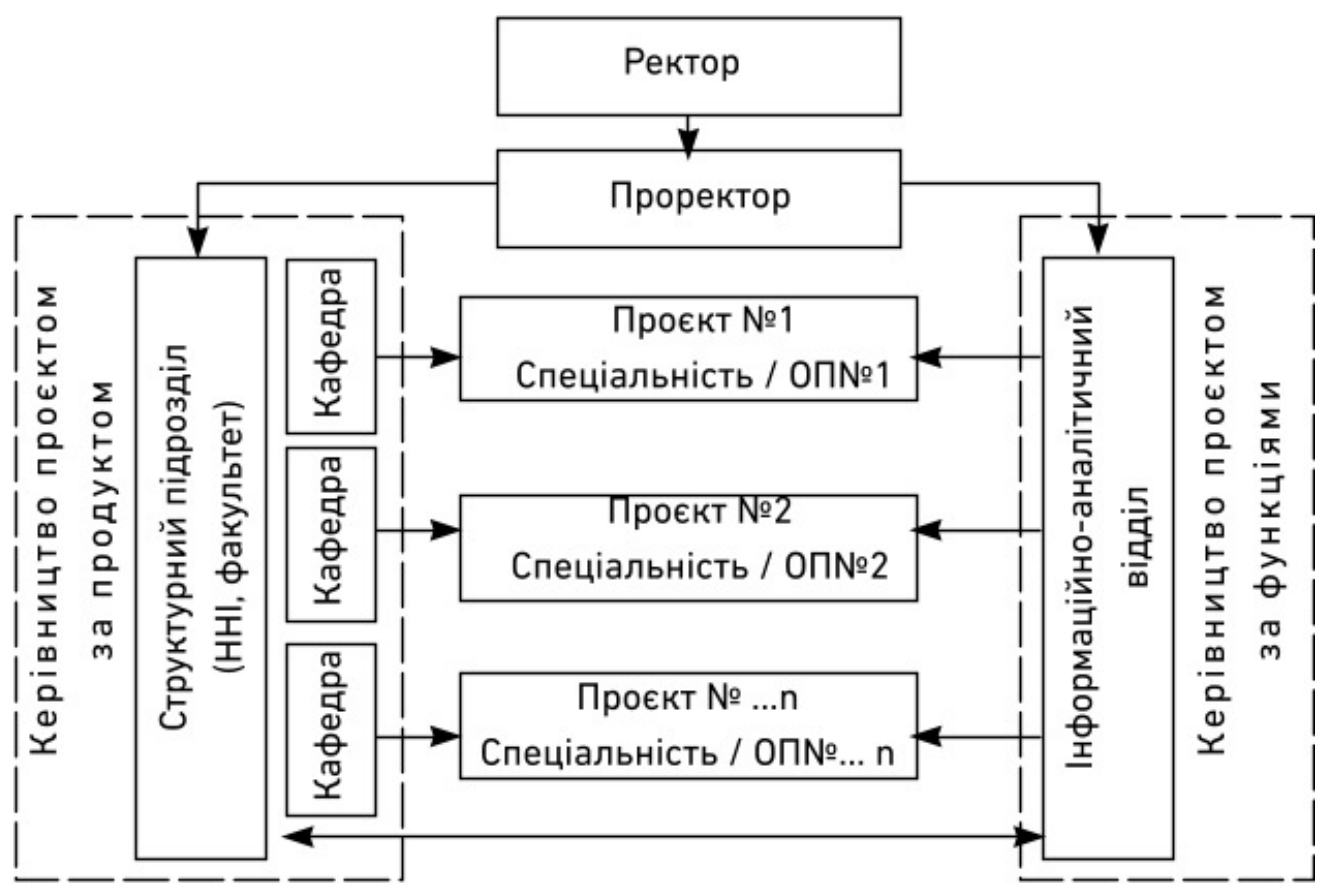

Рисунок. Структура організації роботи інформаційно-аналітичного відділу Джерело: розробка автора за матеріалами [5]

Основні функції інформаційно-аналітичного відділу можуть бути поділені на види:

1. Інформаційно-аналітична діяльність для прийняття рішення про відкриття нових спеціальностей (освітніх програм) :

- дослідження та аналіз позиціонування спеціальності (освітньої програми) на ринку освітніх послуг;

- дослідження та аналіз потреб та попиту ринку праці на спеціальність (освітню програму);

- дослідження та аналіз потреб стейкхолдерів та виявлення оцінки тієї цінності, яку б вони хотіли отримати від реалізації освітньої програми; 
- здійснення аналізу про відповідність спеціальності (освітньої програми) стратегічним та тактичним цілям закладу вищої освіти;

- здійснення аналізу відповідності наявного кадрового, матеріально-технічного та інформаційного забезпечення ліцензійним умовам провадження освітньої діяльності за спеціальністю (освітньою програмою);

- здійснення аналізу наявного фінансового потенціалу та необхідних додаткових фінансових затрат для запровадження освітньої діяльності за спеціальністю (освітньою програмою);

- прогноз економічної ефективності реалізації спеціальності (освітньої програми);

- підготовка на основі проведених досліджень пропозицій керівництву закладу вищої освіти щодо започаткування освітньої діяльності за спеціальністю (освітньою програмою);

- розробка комплексної програми виходу спеціальності (освітньої програми) на конкретний ринок.

2. Інформаційно-аналітична діяльність під час провадження спеціальності (освітньої програми):

- координує діяльність керівника освітньої програми щодо вивчення задоволеності внутрішніх та зовнішніх стейкхолдерів якістю освітньої програми та освітнього процесу;

- готує аналітичний звіт щодо ефективності реалізації комплексної програми виходу спеціальності (освітньої програми) на ринок.

3. Здійснення іншої інформаційно-аналітичної діяльності:

- проведення системних досліджень ринку освітніх послуг та ринку праці, їхньої кон'юнктури, потреби та попиту, динаміки змін на ринках;

- формування об'єктивного прогнозу ринку освітніх послуг із врахуванням специфіки та підготовка пропозицій щодо розвитку спеціальностей та освітніх програм закладу вищої освіти;

- прогнозування майбутніх вимог до фахівців, компетентностей та програмних результатів за спеціальностями, за якими здійснює освітню діяльність заклад вищої освіти;

- формування комунікативної політики зі стейкхолдерами;

- бере участь у визначенні цінової політики освітніх послуг;

- бере участь у визначені та розробці програм стратегічного та оперативного розвитку закладу вищої освіти;

- бере участь у визначені ефективності всього спектру маркетингової діяльності закладу вищої освіти. 
Висновки. Зважаючи, що ринок освітніх послуг за останні роки трансформувався, система ліцензування освітньої діяльності у сфері вищої освіти зазнала значних змін, прийняття управлінських рішень та розробка стратегії розвитку закладу вищої освіти має враховувати специфічність товару - освітньої послуги, з яким заклад освіти виходить на ринок товарів та послуг. Прийняття обгрунтованих управлінських рішень, зокрема, щодо започаткування освітньої діяльності за новими спеціальностями або освітніми програмами не можливе без попередньої глибокої інформаційної та аналітичної роботи. Створення в закладі вищої освіти інформаційноїаналітичного відділу дозволить мати та оперувати актуальною інформацією про ринок праці, ринок освітніх послуг, конкурентів на даному ринку, дасть можливість; 1) створювати умови, за яких заклад вищої освіти зможе мати оперативну інформацію для перегляду номенклатури освітніх послуг - спеціальностей та освітніх програм, 3 метою їх оптимізації, або модернізації 3 метою привабливості для стейкхолдерів; 2) приймати рішення про відкриття нових спеціальностей та освітніх програм чітко усвідомлюючи свої позиції на ринку тієї освітньої послуги, яка започатковується; 3) розробляти новий інноваційно якісний продукт, який коритуватиметься попитом зі сторони абітурієнтів та їхніх батьків; 4) формувати конкурентні переваги; 5) дозволить приймати обґрунтовані рішення, спрямовані на досягнення економічного ефекту, для більш раціонального використання наявних ресурсів ще на етапі розгляду питання про доцільність започаткування освітньої діяльності за новими спеціальностями або освітніми програмами.

1. Оболенська Т. Є. Маркетинг у сфері освітніх послуг : автореф. ... д-ра екон. наук : 08.06.02 / Харк. держ. екон. ун-т. Х., 2002. 33 с. 2. Василькова Н. В. Стратегічне маркетингове планування у вищому навчальному закладі. Економіка та підприємництво: зб. наук. праць молодих учених та аспірантів. У 2 ч. Ч. 1. 2015. Вип. 34-35. С.6-14. 3. Решетнікова І.Л. Студент як споживач освітніх послуг у системі маркетингу вищого навчального закладу. Економіка та підприємництво : зб. наук. пр. молодих учених та аспірантів. У 2 ч. Ч. 1. 2015. Вип. 34-35. С. 59-67. 4. Решетнікова І.Л. Маркетингове забезпечення конкурентоспроможності вищих навчальних закладів. Маркетинг в Україні. 2010. № 4. С. 67-70. 5. Сабурова М. М. Организация работы отдела маркетинга: теория и практика : учебник. Ульяновск : УлГТУ, 2017. 236 с. 6. Маркетингова політика закладу вищої освіти: колективна монографія / за заг. ред. Н. Л. Савицької. Х. : ХДУХТ, 2018. 163 с. 7. Жегус О. В. Ринок послуг вищої освіти як основа маркетингової діяльності вищого навчального закладу. Економічна стратегія і перспективи розвитку сфери торгівлі та послуг: зб. наук. праць / редкол. О. І. Черевко (відпов. ред.) та ін. Харків: ХДУХТ, 2017. Вип. 1 (25). С. 269-281. 8. Якимчук А. Ю. Інтернаціоналізація діяльності сучасного університету: імплементація заходів підвищення якості освіти. Інноваційний 
Серія «Економічні науки»

Випуск 2(90) 2020 p.

університет і лідерство: проект і мікропроекти - III : зб. статей / відповідальні редактори Т. Фініков, Р. Сухарські. Варшава: Wydziat „Artes Liberales” UW. 2019. 412 с. С. 122-130. ISBN 978-83-63636-84-5. 9. Климова А. Государственное регулирование хозяйственной деятельности высших учебных заведений Украины на примере лицензирования образовательной деятельности. International Journal of New Economics and Social Sciences. 2017. № 2 (6). С. 349-358. 10. Якимчук А. Ю., Клімова А. В. Інструменти вдосконалення системи ліцензування закладів вищої освіти: економічні аспекти запровадження міжнародного досвіду. Вісник Національного університету водного господарства та природокористування. Сер. Економічні науки. 2019. № 4 (88). С. 365-377. 11. Клімова А. В. Інституційні основи ліцензування освітньої діяльності у сфері вищої освіти України. Інвестиції : практика та досвід. Сер. Економічні науки. 2019. № 10. С. 65-72.

\section{REFERENCES:}

1. Obolenska T. Ye. Marketynh u sferi osvitnikh posluh : avtoref. ... d-ra ekon. nauk : 08.06.02 / Khark. derzh. ekon. un-t. Kh., 2002. 33 s. 2. Vasylkova N. V. Stratehichne marketynhove planuvannia u vyshchomu navchalnomu zakladi. Ekonomika ta pidpryiemnytstvo: zb. nauk. prats molodykh uchenykh ta aspirantiv. U 2 ch. Ch. 1. 2015. Vyp. 34-35. S. 6-14. 3. Reshetnikova I. L. Student yak spozhyvach osvitnikh posluh u systemi marketynhu vyshchoho navchalnoho zakladu. Ekonomika ta pidpryiemnytstvo : zb. nauk. pr. molodykh uchenykh ta aspirantiv. U 2 ch. Ch. 1. 2015. Vyp. 34-35. S. 5967. 4. Reshetnikova I. L. Marketynhove zabezpechennia konkurentospromozhnosti vyshchykh navchalnykh zakladiv. Marketynh v Ukraini. 2010. № 4. S. 67-70. 5. Saburova M. M. Organizatsiya rabotyi otdela marketinga: teoriya i praktika : uchebnik. Ulyanovsk: UIGTU, 2017. 236 s. 6. Marketynhova polityka zakladu vyshchoi osvity : kolektyvna monohrafiia / za zah. red. N. L. Savytskoi. Kh. : KhDUKhT, 2018. 163 s. 7. Zhehus 0 . V. Rynok posluh vyshchoi osvity yak osnova marketynhovoi diialnosti vyshchoho navchalnoho zakladu. Ekonomichna stratehiia i perspektyvy rozvytku sfery torhivli ta posluh : zb. nauk. prats / redkol. 0. I. Cherevko (vidpov. red.) ta in. Kharkiv : KhDUKhT, 2017. Vyp. 1 (25). S. 269-281. 8. Yakymchuk A. Yu. Internatsionalizatsiia diialnosti suchasnoho universytetu: implementatsiia zakhodiv pidvyshchennia yakosti osvity. Innovatsiinyi universytet $i$ liderstvo : proekt i mikroproekty - III : zb. statei I vidpovidalni redaktory T. Finikov, R. Sukharski. Varshava : Wydziat „Artes Liberales" UW. 2019. 412 c. C. 122-130. ISBN 978-83-63636-84-5. 9. Klimova A. Gosudarstvennoe regulirovanie hozyaystvennoy deyatelnosti vyisshih uchebnyih zavedeniy Ukrainyi na primere litsenzirovaniya obrazovatelnoy deyatelnosti. International Journal of New Economics and Social Sciences. 2017. № 2 (6). S. 349-358. 10. Yakymchuk A. Yu., Klimova A. V. Instrumenty vdoskonalennia systemy litsenzuvannia zakladiv vyshchoi osvity: ekonomichni aspekty zaprovadzhennia mizhnarodnoho dosvidu. Visnyk Natsionalnoho universytetu vodnoho hospodarstva ta pryrodokorystuvannia. Ser. Ekonomichni nauky. 2019. № 4 (88). S. 365-377. 11. Klimova A. V. Instytutsiini osnovy litsenzuvannia osvitnoi diialnosti u sferi vyshchoi osvity Ukrainy. Investytsii : praktyka ta dosvid. Ser. Ekonomichni nauky. 2019. № 10. S. 65-72. 
Klimova A. V. [1; ORCID ID: 0000-0003-0051-3925]

Post-graduate Student, Head of the Department of Licensing and

Accreditation

${ }^{1}$ National University of Water and Environmental Engineering, Rivne

\section{IMPROVEMENT OF THE ORGANIZATIONAL STRUCTURE OF HIGHER EDUCATION INSTITUTIONS IN ORDER TO INCREASE THE EFFICIENCY OF LICENSING AND ECONOMIC ACTIVITIES}

The active entry of Ukrainian higher education institutions into the European educational space, demographic decline, which strengthens competition on the market of educational services, the reform of the system of higher education, the system of licensing of educational activities, the introduction of autonomy of higher education institutions, including academic and financial, makes it necessary for educational institutions to elaborate new development strategies and requires the use of new tools and marketing technologies. Marketing of educational services is intended to form strategies and tactics of behavior on the market of educational services. Taking into consideration that educational institutions enter the market with a specific product, such as an educational service, the formation of which should be based on the needs of internal and external stakeholders, it is necessary to pay attention to the completeness of information and analytical support prior to making managerial decisions. This article analyzes the sufficiency of information and analytical support of decision making of universities on entering new sectors of the market of educational services, making decisions on introducing new educational programs and improving the existing ones. Ways to improve the organizational structure of higher education institutions are proposed in order to elaborate new development strategies to stimulate economic performance and increase the efficiency of licensing activities. The social and economic impact of the proposed activities is described in order to make informed management decisions.

Keywords: licensing; economy; higher education institutions; labour market; educational services market; management strategy; information and analytical activity. 
Климова А. В. ${ }^{[1 ; 0 R C I D ~ I D: ~ 0000-0003-0051-3925], ~}$ соискатель высшего образования третьего (образовательнонаучного) уровня, заведующая отделом лицензирования и аккредитации

${ }^{1}$ Национальный университет водного хозяйства и природопользования, г. Ровно

\section{СОВЕРШЕНСТВОВАНИЕ ОРГАНИЗАЦИОННОЙ СТРУКТУРЫ ВЫСШИХ УЧЕБНЫХ ЗАВЕДЕНИЙ С ЦЕЛЬЮ ПОВЫШЕНИЯ ЭФФЕКТИВНОСТИ ЛИЦЕНЗИОННОЙ И ХОЗЯЙСТВЕННОЙ ДЕЯТЕЛЬНОСТИ}

Активное вхождение высших учебных заведений Украины в Европейское пространство высшего образования, демографический спад, который увеличивает конкуренцию на рынке образовательных услуг, реформирование системы высшего образования, системы лицензирования образовательной деятельности, введение автономии высших учебных заведений, в т.ч. академической и финансовой, ставит перед учебными заведениями необходимость разрабатывать новые стратегии развития, требует применения новых инструментариев и технологий маркетинга. Целью маркетинга образовательных услуг является формирование высшими учебными заведениями стратегии и тактики поведения на рынке образовательных услуг. Учитывая то, что учебные заведения выходят на рынок со специфическим товаром, таким как образовательная услуга, формирование которого должно базироваться на потребностях внутренних и внешних стейкхолдеров, необходимо обратить внимание на полноту информационноаналитической деятельности, предшествующей принятию управленческих решений. В данной статье проведен анализ достаточности информационного и аналитического обеспечения принятия решений высшими учебными заведениями о вхождении в новые секторы рынка образовательных услуг, принятия решений о введении новых образовательных програм и усовершенствование существующих. Предложены направления совершенствования организационной структуры учреждений высшего образования с целью разработки новых стратегий развития для стимулирования экономических результатов хозяйственной деятельности и повышения эффективности лицензионной деятельности. Описано социальноэкономическое влияние предложенных мероприятий с целью принятия обоснованных управленческих решений.

Ключевые слова: лицензирование; экономика; высшие учебные заведения; рынок труда; рынок образовательных услуг; стратегия управления; информационно-аналитическая деятельность. 